\title{
Müellifi Bilinmeyen Bir Tıp Sözlüğü
}

\section{Sibel MURAD ${ }^{1}$}

\author{
APA: Murad, S. (2018). Müellifi Bilinmeyen Bir Tıp Sözlüğü. RumeliDE Dil ve Edebiyat \\ Araştırmaları Dergisi, (12), 35-67. DOI: 10.2900o/rumelide.472751
}

\begin{abstract}
$\ddot{\mathbf{O} z}$
Sözlükler, bir dilin söz varlı̆̆ını ortaya koymaları, başka dildeki sözcüklerin öğrenilmesi, bir alanla ilgili terimleri barındırması gibi birçok bakımdan önemli eserlerdir. Bilhassa belirli bir alana ait olan sözcüklerin yer aldığı terim/alan sözlükleri yazıldıkları alana ve ilgili kişilere hizmet ederler. 14 yüzyıldan sonra birçok bilim dalıyla ilgili eserler verilmiştir. Bunlar arasında tıp ve sağlıkla ilgili metinler de bulunmaktadır. Tıp ve eczacılıkta kullanılan birçok yabancı bitki, terkip, ilaç, aş, cevher vs.nin başka dillerdeki karşlıklarını veren müstakil olarak hazırlanmış tıp-ecza sözlüklerinin yazımına ise 17. yüzyıldan itibaren başlanmıştır. Çalışmamızda Prof. Dr. Mehmet Fatih Köksal'ın şahsî kütüphanesinde bulunan müellifi, müstensihi ve yazllış tarihi bilinmeyen bir tıp sözlüğü tanıtılarak metni sunulacaktır. Eser 16 yaprak olup baş tarafı eksiktir. Üç "fasıl”dan oluşan eserin ilk faslında tıbbî özellikteki bitki, ilaç adlarının Türkçe, Arapça, Farsça ve Boşnakça -bir kelimenin Ermenice- karşılıkları yer almakta, ikinci fasılda insan vücudunda bulunan kan, safra, balgam, sevda unsurlarının oranlarına göre insan mizacına nasıl etki ettikleri ve bunlara göre insan tabiatları tanıtılmaktadır. Son fasılda ise birçok hastalık adının Türkçe, Arapça ve Farsça karşılıkları bulunmaktadır. Sözlüğün madde başları çoğunlukla Arapça, Farsça olup yer yer Türkçe madde başlarına da rastlanmaktadır. Çalışmamızda, çeşitli bitkilerin, devaların, hastalıkların Arapça, Farsça, Türkçe ve Boşnakça karşlıklarının bulunduğu söz konusu sözlük tanıtılarak çeviriyazı alfabesiyle metni sunulacaktır.
\end{abstract}

Anahtar kelimeler: Tıp Sözlüğü, ecza sözlüğü, bitki, ilaç, hastalık.

\section{A Medical Dictionary With An Unknown Author}

\begin{abstract}
Dictionaries are important works in many ways, such as revealing the existence of a language, learning other words, and accommodating terms related to a field. In particular, the terms / field dictionaries in which a word belongs to a specific field are served in the field in which they are written and related persons. There are also works related to medicine and health among the works taken many sciences related works in Turkish after the 14th century. However it has been started since the 17th century for the writing of self-made medicine-pharmacy dictionaries, which give the name of many foreign plants, preparations, medicines, fodder and ores used in the field of medicinepharmacy their equivalents in other languages such as Turkish or Arabic, Farsi. In our work, we will present a medical dictionary that situated in the personal library of Professor Dr. Mehmet Fatih Köksal and does not know who wrote and on which date it was written. The work has 16 leaves and the starting side of the work is missing. There are three chapters in the content of the work. In the first chapter, the medicinal names of the plants and medicines in the medicinal properties are Turkish, Arabic, Persian and Bosnian equivalents. In the second chapter, human beings are ORCID ID: 0000-0003-0175-7702 [Makale kayt tarihi: 9.8.2018-kabul tarihi: 6.10.2018]


introduced. In the last chapter, many diseases have Turkish, Arabic and Persian meanings. The headings of the dictionary are mainly Arabic, Persian and occasionally found in Turkish headings. In our work, this dictionary with the meanings of various plants, treatments, diseases of Arabic, Persian, Turkish and Bosnian will be introduced and the text will be presented with the transliteration alphabet.

Key words: Medical dictionaries, pharmacy dictionaries, plant, medicine, disease.

\section{Giriş}

Tıp konulu eserler, insanın var olduğu her dönemde şüphesiz önemli bir yere sahip olmuştur. Türkçe tıp konulu eserlere Uygurlardan bu yana rastlanmaktadır. Anadolu'da ise önceleri tercümelerle başlayan tıp konulu eserlerin yazımına 14. yüzyıldan itibaren başlandığı bilinmektedir. İnsan sağlığını ilgilendiren çeşitli devaların, terkiplerin tariflerinin de yer aldığı bu eserlerde birçok bitki, cevher, aş ve terkip adları bulunur. Söz konusu eserleri daha iyi anlayabilmek için eserlerde yer alan yabancı bitki, terkip, cevher, aş ve hastalık adlarının Türkçe karşılıklarının yer aldığı müstakil tıp-ecza sözlüklerinin yazımına 17. yüzyldan sonra başlanmıştır. Bu yüzyıldan önce ise tıp sözlükleri, bazı tıp kitaplarının içinde yer almıştır.² Bilinen müstakil ilk tıp-ecza sözlüğü, Lugat-ı Müşkilât-ı Eczâ'dır. 3

Çalışmamıza konu edindiğimiz tıp sözlüklerinden biri olan eser, Prof. Dr. Mehmet Fatih Köksal'ın şahsî kütüphanesinde4 bulunan bir yazmanın içinde yer alan iki kitaptan biridir. Mec. 97/1 numaralı bir mecmuada yer alan sözlük, harekesiz nesih hatla yazılmış olup 1a-15b sayfaları arasında bulunmaktadır. Satır sayısı bazı sayfalarda daha az olmak üzere genellikle 17 satırdır. Madde başları ve fasıl başlıkları kırmızı mürekkeple yazılmıştır. Müellifi ve müstensihi belli olmayan eserde herhangi bir tarih kaydı bulunmamaktadır. Yazmada yer alan Bâdnâme adlı diğer eser ise 16a'da başlayıp 48b'de sonlanmaktadır.

Bir tıp sözlüğü olan eserde Türkçe, Arapça, Farsça ve Boşnakça birçok bitki, deva ve hastalık adlarının Türkçe karşılıkları ya da daha çok kullanılan, bilinen farklı dillerdeki karşılıkları verilmektedir. Sadece bir bitkinin de (ḳunāberā) Ermenice karşıllğı verilmiştir.

Üç fasıl içeren eserin ilk faslı 1a-11b sayfaları arasında yer alan ecza sözlügüdür. Sözlüğün baş tarafı eksik olup "ḳoġalık otı" maddesiyle başlamaktadır. Bu bölümde genellikle Arapça, Farsça olan tıbbî özellikli birçok bitkinin, devanın çoğunlukla Türkçe karşlıkları verilmiştir. Maddeler alfabetik olarak sıralanırken sözcüklerin sadece ilk harfleri dikkate alınmıştır.

Eserin 11b sayfasında, insan tabiatlarının özelliklerini anlatan "fașl fí żamāyiri'l-insān ve tabāyi uhum" başlıklı ikinci faslı yer almaktadır. Eski tıbba göre insan vücudunda bulunan ve ahlât-ı erbaa olarak bilinen 4 hılt (kan, safra, balgam ve sevda), vücutta bulunma oranlarına göre insan tabiatını etkilemektedir. Bu fasılda demevî, safravî, balgamî ve sevdâvî mizaçların özellikleri anlatılmaktadır.

Eserin 11b-15b yaprakları arasında yer alan üçüncü ve son faslında ise bazı Arapça, Farsça, Türkçe hastalık adları yer almaktadır. Bu faslın başında kısa bir giriş bulunmaktadır. Burada, hekim olan kişinin hastalığın adını bilmediği takdirde doğru teşhiste ve tedavide bulunamayacağı ve böyle kişiye hekim

Ayrıntılı bilgi için bk. Doğan, 2012, s.104.

Ayrıntılı bilgi için bk. Murad, 2009.

Prof. Dr. Mehmet Fatih KÖKSAL'ın koleksiyonunda bulunan yazma eserler Amasya Üniversitesi BAP birimi tarafından desteklenen bir projeyle kataloglaştırılmıştır (Köksal, vd, 2018: 508). Eseri neşretmemize izin verdiği için kendisine çok teşekkür ederiz. 
denilemeyeceği söylenerek her hastalığın devasının bulunduğu, insanda türlü türü hastalıklar olduğu ve bunların tamamını Allah'tan başkasının bilemeyeceği, derdin de dermanın da Allah'tan olduğu ifade edilmiştir. Allah'ın her şeyden zerre kadarını insana malum ettiğini ve malum olunan hastalıklardan binde birinin isimlerinin verileceği söylenerek hastalık faslı başlamaktadır:

Bir ḥekīm her maraż ve her ḥastalıġı ki ismin bilmese ana dahı 'ilāc ètmek bilmez ve ana hekīm dènilmez. Zīrā maraẓa göre devālar bulur ve 'ilāc olınur. İmdi insānda niçe bị hastalık vardur, Allāh'dan ġayrı kimse bilmez. Ve ‘ilāc ètmege bilmez hekīm Allāh'dur. Ancak Allāhu Te`ālā insānı sebeb ve 'illet eyledi. Her şey’den bir zeerre, deryādan nīm-ḳaṭre irādet-i cüz'īye vèrdi, kullarına bildürdi. Binde birin diyevüz. Ol esāmīler bunlardur ki zikr olınur. (11b)

Sözlükteki madde başlarının çoğunlukla Arapça ve Farsça sözcüklerden oluştuğunu görmekteyiz. Çok sık olmasa da Türkçe madde başlarına da rastlanmaktadır: "Meryem ana eli, yılan boncuğu, yüzerlik" vb.

Bazı sözcükler, birkaç kere madde başı olarak kullanılmıştır. Tekrarlanan maddeler şunlardır: kācīre, kāfūr-siperm, kebest, kelūl, keşūr, kīkīr, köknār, kuş etmegi, kūşād, kündüs, merzengūş, mī'a, muḳl, nāk, nānḥuvān, nārdīn, yezġand; žātü'l-cenb, sersām, remed, mālihūlyā, laḳve, dā'ü’ṣ-șa'leb, bevāṣīr, baraṣ. Tekrarlanan madde başı sözcüklerin genel anlamı değişmese de açılamalarında değişiklikler bulunmaktadır:

Kīkirr: Kerdeme ısırǵan toḥmına dèrler. (4a)

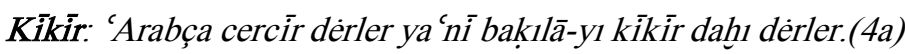

Z̄âtü 'l-cenb: dèrler bir marażdur ki eyegü ağrIsıdur.(12b)

Zātü̉ '-cenb: dèrler bir marażdur.(14a)

Tip ve ecza sözlüklerinde yer alan bitki, deva, terkip, cevher ve aş adları genellikle Arapça, Farsça, Grekçe, Türkçe, Rumca gibi dillere aittir. Bu sözlükte tıp ve ecza sözlüklerinde sık rastlanmayan bir özellik de 23 adet bitki adının Boşnakça karşlıklarının verilmesidir. Bu sözcüklerden "silez, imel ve imele" sözcükleri harekelenmiştir. Aynı zamanda sözlükte Boşnakça olarak verilen bazı bitki adları bugünkü Boşnakçada da yer almaktadır:

Ebegömeci (Malva siylvestris) bitkisi metinde "silez" olarak harekelenmiş olup bugünkü Boşnak dilinde de "slez" olarak kullanılmaktadır.

Maş fasülyesi, kara börülce (Phaseolus aureus) anlamlarında metinde Bosna dilinde "ġırah" olarak karşıllğı verilen sözcük bugünkü Sırpçada fasülye karşılı̆̆ında “грах-ġrah” olarak bulunmaktadır.

Ayrık otunun (Agropyrum repens) Boşnakça karşılığı olarak verilen "pirevān" sözcüğü, günümüz Boşnakçasında "pirevina"dır.

Metinde rezene (Foeniculum vulgare) karşıllğında verilen Boşnakça "morāc" sözcüğü "morač" olarak, sığırkuyruğu (Verbascum) karşllığında verilen "dìvīzma" sözcüğü "divizma” olarak günümüzde de yaşamaktadır.

Sözlükte tıpta kullanılan birçok bitkinin Arapça, Farsça, Boşnakça ve Türkçedeki karşllıklarının bulunmasının yanı sıra Amasya, Bursa, Kırım vs. gibi yerlerde bu bitkilere verilen adlardan da 
bahsedilmektedir: "Amāsya diyārında manuk dèrler (1b); Būrsa șehrinde kurtlu ot derler ve Kırım'da da kurtlu ot (1a)."

Bazı Arapça, Farsça madde başları asıllarından farklı olarak yazılmıştır. Metinde " 'arūs perde" olarak geçen kanbil otunun Farsçadaki şekli 'arûs der perde'dir. Güneyik otunun Farsça karşılığı olarak verilen “ḥaşkūḳ" sözcüğü ise "ṭarḥaşkūḳ̣” olmalıdır.

Metnin imlasına dair tespitlerimiz şöyledir:

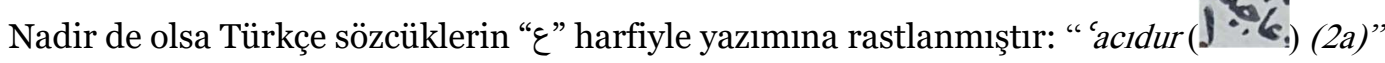

Metinde bazı sözcüklerin yanlış yazıldığı görülmektedir. Türkçe "gevşek” anlamına gelen Farsça "süst” sözcüğü “sest” olarak harekelenmiştir: "süstlığını

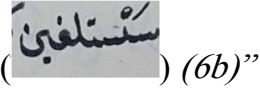

Harekesiz olan metinde okunmasında güçlük çekileceği düşünülen bazı Türkçe ve Boşnakça sözcüklere

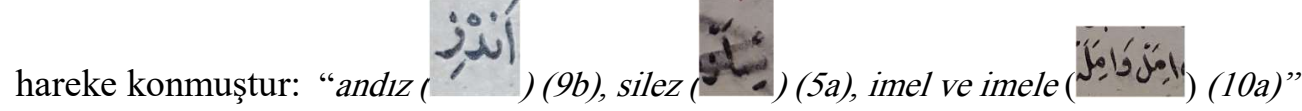

Tıbbî bitkilerin faydalarından bahsedildiği örnekler azdır. Genellikle bitkinin diğer dillerdeki ya da Türkçedeki karşılığının ardından tarifi verilmektedir: "Mürver: Dérler bir ag̉açdur. Bahārınuı șuyı tașaya ve gögül dönmesine nāfí 'dür. (7a)’

Bazı madde başlarında adları verilen bitkilerin diğer dillerdeki karşılıkları yer almayıp sadece bitkinin özelliklerinden bahsedilmiş̧ir: "Kettān toḥm: Hārdur, ammā yübüsetde ve rutübetde mu tedildür. (4b)"

Bazen de madde başında bulunan bitki hakkında ayrıntılı bir bilgi verilmemiştir: "Kelem: Bir meşhūr otdur (5a), Mentūr: Bir çiçekdür (6a), Māzū: Ma 'rüfdur (6b)'

Madde başında verilen hastalıkların bazen sadece Türkçe veya başka dildeki karşılı̆̆ı verilmiş, açıklama yapılmamıştır: "Uyuz 'illeti: 'Acem ețibbāsı kerū ve 'Arab cereb dèr."

Bazen sadece yabancı dildeki madde başının Türkçe karşıllğı verilmiştir: "Hafakān: Yürek oynamasıdur (12a), Yerakān: Sarılık marażıdur (12a)’

Hastalıkların tarif edildiği örneklere de rastlanmaktadır:

Ur 'illeti: Bir marażdur ki ana 'Acem ețibbāsı ḥacş dèr, 'Arab țabībler sal'a dèr. Ādemün gövdesinde çıkar. Bādıncān ve karpūz dẹlü olur. Hīç ağrımaz. (12a)

Eserin sayfa kenarlarında bazı hastalıkların açıklaması yapıldıktan sonra bu hastalığa iyi gelen ilaç tarifleri verilmiştir:

mādde vü imtilādan olan hastalıkları 'alāmetleri oldur kim bundan ö̉din ittifāk düssmiş ola kim ag̉rılu ḳomalar ve çok yèmek yèmiş ola. Ve bedeni ağır ola ve kāhil ola, güç deprene. Ve țamarları boş olduğınủ 'alāmeti oldur kim

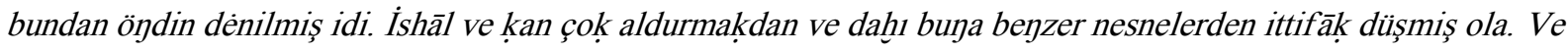


țabībü̈ 'ādeti oldur kim kaçan imtilā görse eydür kim bir mādde var dèr. Mādde yā issi yā șovuk ola yā kan ola yā șafrāà ola. Șovuk mādde yā balg̀am ola yā sevdā’ola.

Sersām: Devāsı baș ağrısındadur. Sersām iki dürlüdür. Birisi oldur kim anuy māddesi șafrā-yı hāliṣ ola ve

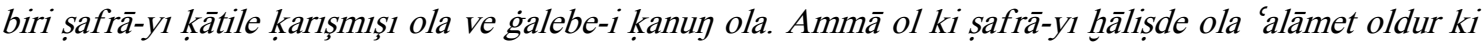
anun issi sıtma ve uykusuzluk ola. Ve beyhüde sözler söyleye ve șușaya ve aǵzı kurı ve acı ola. Bepzi șarı ve dili iri ola.

‘İāc: Ak sandal gülāb ile ezeler. Azacık kāfūr ve sirke tamzurup kokudalar. Gögsine dürteler. Nāfi‘ ola.

Maraż-1 Mālịhūlyāa: Māliḥūlyā dīvānelikdür. 'Alāmeti tahayyürlık, mi'dede ve bagiı̆rsaklarda yèller olmaḳdur kim yèllerin buhârı dimāga çıka ve dürlü dürlü fikrler ètmekdür ve dā’im melūl olmakdur ve nevmīd ve korḥulu olmaḳdur. Her kişiden da’im devā taleb ètmekdür. Teşviş̧lenmekdür. Çok çok tenkıyeler ètmek gerekdür. Ve yassılık tamarından șol elinden kan almak gerek ve müshil vérmek gerek. Üçünci gafletden ve ümīdsizlıkdan 'ilāc ḥukne èdeler ve āyāric-i fayḳarā uralar ve şaḥm-1 hantal ve gargarara ètdüreler. Bu șifatluya 'ākırkarhā ve mevīzec ve hardal ve kebere köki bal-1la dögüp ve eleyüp bal-1la karışduralar. ābkāmeyle ezeler, garg̉ara ètdüreler. Bulunmaz ise sirke ile ezeler ve her sabāḥ iki dirhem ma'cūn-1 lübānì vèreler. (11b)

Ma'cūn-1 lübān: Günlük, egir, topalak, dār-1 fülfül, zencebīl. Her birinden berāber dögeler, eleyeler berāberi 'asel ile karışduralar. Arpa içinde kırk gün șaklayalar. Andan yapalar şerbet iki dirhemden ġ̀da kavurma kālyeler ve noḥūd, āb, ḳoz yağlyla nāfic ola. (12a)

Dördünci sekte marażıdur. Sekte kusmak ile def $f^{c}$ olur.

Beşinci șar'dur ve baş çegzinmekdür. Șar'a dedükleri bir süddedür ki dimāğgun yolında tagigllur ve rūhh-1 nef sānī nefür ètmekden men 'èder. Bu sevdāda yā balgamda olur. Kandan șafrādan dahı olur. Süddeyi hal

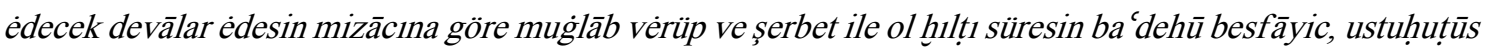
ve 'ạkırkarhā berāber èdüp dögeler ve eleyüp çekirdegi çıkmış ḳızıl üzüm ile yogururalar ve ta āàmdan evvel

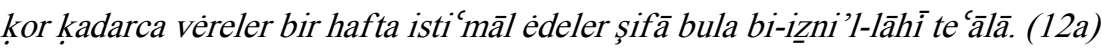

Yine eserin sayfa kenarında bâb başlığı altında verilen iki ilaç tarifi bulunmaktadır:

Bāb: Tatar kurdına: Koyun kemügi yakup kül ède, ba 'dehū ince bèzden geçüreler bal ile ma ćūn èdüp bir nice gūne yèye, bi-emr-i Hudā cümle kurdı helāk èdüp kıra, ma 'lūl ḥalās ola. Biz hakịir tecrībe etdük, șahịh bulduk gaflet olunmaya. (4b)

Bāb: Oġul ḳı getürmeyen 'avratlara, gàayet nāfi'dür. Çörek otı toḥm 10 dirhem, cūb-ı çinī 10 dirhem, maștakī 6 dirhem, beyāz tự ‘: 15 dirhem, beyāz fülfül 2,5 dirhem, zencebīl 2,5 dirhem, kākūle 2 dirhem, türbid 4 dirhem, maḥmūde 10 dirhem, rāvend-i çinī 10 dirhem, sināmekī 10 dirhem; 'asel-i mușaffā 450 dirhem. Üçer dirhem aç karnına yėyeler, nef'ini müşāhede kılalar. Fā’idesi görile. (9b)

11a sayfa kenarında başka bir yazıyla yazılmış bir adet çocuk ilacı mevcuttur: "çocuklar içün ma'cūn: hindistān cevizi 1 miktel; defne kezā; kākūle kezā; bal oṭı kezā, alı oṭı kezā; talmiyān (?) kezā; bādem 3 miktel; șūsām 2; 'aṣfür 1 miktel, șeker 100 dirhem." 


\section{Çeviriyazılı Metin}

\section{[1a]}

Koggalık: Dẻrler bir otdur ki sāzdur. 'Acem esel dèrler, șulu yẻrlerde biter.

Ḳıçı otı: Ki aya pendū dèrler, ma' rūfdur.

Ḳara yonca: 'Arabça ḥandakūḳ dèrler.

Kurudan: Bir otdur ki aja 'Acem şābīzek dèr. Ṭabībler katında lüffāḥ dèrler.

Kāḳulī: Bir ot adıdur ki çog̉ana beyzer. Çog̉andan yaşıllıġı artıkdur. 'Arabça ḳullām dẻrler. Müshildür. Șaru șu süzdürür, ruțūbeti tahfīif èder.

Kunāberā: Ermenīler hịīūk dèdükleri otdur.

Ḳurdumān: Ki ana ekin ṣarısı dèrler. Fesbiyūn dahı ferikāa ve fer dèdükleri otdur.

Ferfiyūn: Kebābe dedükleri edviyedür.

Ḳanbil țayag̀ı: Dẻrler bir otdur ki it üzüminün bir nev'idür.

Ḳullām: Bir otdur. Türkīde zülf-i nigār dèrler ve kākulī dahı dèrler.

Ḳımleh: Dėrler bir otdur. 'Acem leblāb ve zet dahı dèrler. 'Arab arāḳ dèyü dèrler.

Kaḳlugaan dikeni: Toḥm[1] bevāṣīre ġāyet eyüdür.

Karaz: Dẻrler bir ag̉açdur. Aḳākiyā dẻrler, erg̉uvān ag̉acı yẻmişine benzer. Katı ḳabżdur.

Ḳafrü’l-yehūd: Dërler bir otdur. Zift gibi olur.

Ḳabìigi: Dẻrler, döngel dahı dẻrler.

Ḳunduz țaşag̀ı Dèrler bir meşhūr dārūdur.

Ḳıșs̄ā ü'l-ḥımār: Bir ma rūf otdur Türkçe düvelecik dibi dèrler.

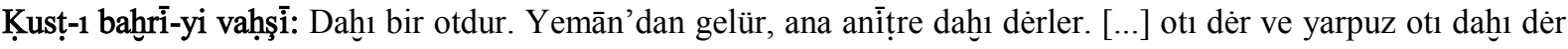
ve Būrsa şehrinde ḳurtlu ot ḍerler ve Ḳırım'da da ḳurtlu ot.

Kurtlu ot: Dẻrler bir ot olur. 'Arabça kündüs dèrler. Bosna lisānında çerīfe dèrler.

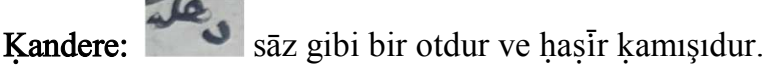




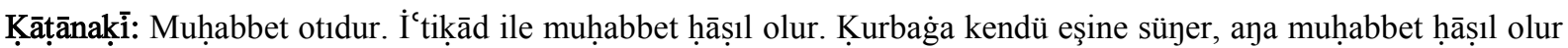
ve ḳaplubag̉adan rivāyet olınur. Uvacık mersīni yapraġı gibi yapraġı olur.

Kurțāṣ-1 muharrak: Dẻrler, berdī dahıı dèrler. Kog̉alık dahı dèrler șulu, bınarlu yẻrlerde çoḳ olur.

Kulkās: Kulkāz otıdur, muctedildür.

Ḳoyun gözi: $\mathrm{Ba}$ ċ̇̀lar pāpādya, bābūnec ve kūpel çiçegidür dèrler.

Karyūs: Buyan balıdur, öksürüge nāfi ${ }^{`}$ dür.

[1b]

Kuş etmegi: Dèrler bir otdur. Yollar kenārında biter. Bī-'aynihỉ tere yapraġına benzer uvacık yapraġı olur güllüce aḳ çiçegi olur țam üzerinde dahı biter 'Arabça ḳuş teresi dèrler.

Ferāsiyūn: Kim Türkçe it siki dèrler.

Ḳarg̉a ḳavunı: Ebū Cehil ḳarpūzı dahı dèrler.

Kulaḳ otı: Dėrler bir otdur yaylalarda olur. Kulaḳ ag̉rısına, teșennüce [nafic $]$ dür. Semiz ot dahı dèrler.

Ḳavur: Vec dèrler bir otdur. Sancuya ġāyet eyüdür.

Ḳıșsā ve Kasased: Hֵıyār.

Kuṭn: Panbuk.

Kunnebīị: 'Acem, kürünb dèrler, bir otdur.

Ḳılır: Dėrler bir otdur. Ḥilāl otı dahıı dèrler.

Kạalık yapragiı: Dérler bir otdur. 'Acem pīl-gūş dèr. Bosna dilinde repūḥ dèrler.

Ḳuş etmegi: Dèrler bir otdur ki bir adı tūderīdür.

Ḳaytemūn: Dėrler bir dürlü șarmaşı̣̣dur.

Ḳamle: Dėrler ve șandaliyū daḩı derler.

\section{Faṣlü'l-ḥarfü'l-kāf}

Gül: Ma rūf ve meşhūrdur. Envāấ1 olur.

Kārşīm: Bir otdur, Türkçe mendik dèrler.

Kelūl: Burçaḳ. [2a] Ṭabībler ḳatında ma rūfdur.

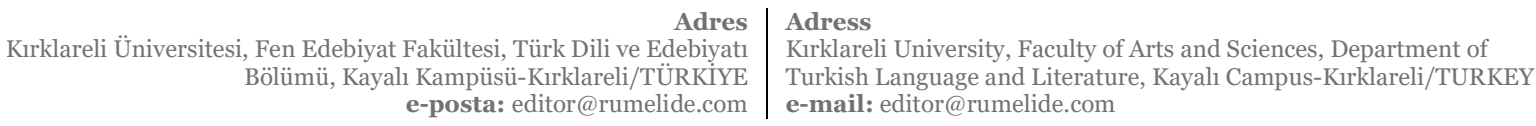


Kākül: Bir ot adıdur ki `Arabca kullām dèrler.

Kāsnī ve ḳaṣnı: Ma'nāsına 'Arab hindibādur. Bir ma '́nūf otdur, būstānlarda biter ve birine acı mārūl dahı̆ı dèrler ve birine datlı mārūl dèrler. Ekerler ve yẻrler ve bir nev' güneyik çiçegidür, güneșe ḳarşu döner.

Kebābe: Meşhūr edviyedür ki ferfiyūn dèrler, ferfiyā dahı dẻrler.

Kebere otı: 'Arabça lașaf dèrler.

Kāknec ve Kākne: Ḳanbīl otı ki it üzüminün bir nev'idür. Nārencì kökleri olur. Ġulāf içinde al renglü üzüm dānesi gibi bāżincān yapraġı gibi yapraġı olur. Aşçılar aşı, anun ile boyadurlar. Yaġlu ve çerb görünsün. Ṭabībler ana Pārsice 'arūs perde dèrler ve dahı ḳanbīl țayaġı dèrler.

Kebīkec ve kebīke: Bir otdur ki șaru çiçegi olur ki aya tere ve dögün çiçegi dèrler. Ba ${ }^{c} \dot{z} 1$ yèrlerde südlügen dèrler.

Kehyānā: Ayu güli ve ayu ḳulag̉ı dèdükleri ot ki eṭibbā ḳatında fāvāniyā ve 'ūdu’ṣ-ṣalīb dèmekle meşhūrdur.

Keçi boynuzi: Dėdükleri yẻmiş ki ana ḩarnūb dèrler.

Kerābe: Bir ma 'rūf otdur.

Keresb: Kereviz dèdükleri otdur ki ma`denūs anuy bir nev`idür.

Kerūh: Ki ana kāt-1 hindī dèrler, dārūdur ki țabī' atı ṣovuḳdan tebrīid içün isti ${ }^{c}$ āl èdilir.

Kerevīz: Bir adı keresbdür. Her kim yèse cimā̄a ḳuvvet vèrür. 'Avratın südini artturur.

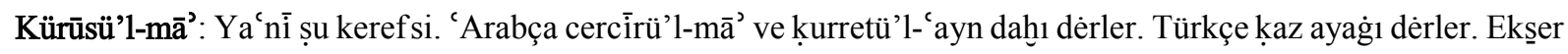
șulan yėrlerde olur.

Kedi ḳyrugig: Dẻrler, bir otdur. Yapraġını dögüp yaraya ekseler oyula.

Kāc: Çam ag̉acı.

Kācire: 'Uṣfūr toḥm.

Kārtene: Boy otı.

Kārḥabek: Ḥıyār.

Kārdū: Ḥurmā çiçegi.

Gār-zeh: Toḥm-1 ' uṣfūr ve kākiyān dèrler.

Kāsnī-yi talh: 
Kāşem: Bir otdur, Amāsya diyārında manuk dèrler.

Kāfūr-siperm: Ak yapraḳlu feslegendür ki `Arabça gubbeyrān dèrler ve bir șaru çiçekdür kāfūr gibi ḳoḳar.

Kālye: Bir otdur țabībler katında ma rūfdur.

Ketre-petre: Bir dikenlü otụ żamġıdur. Ol dikeni deve yėgen olur. Türkīde gön dẻrler gülbetere dahı dèrler.

Ketestū: Uşnān ve mahleb dėdükleri otdur. Anupla giysü yurlar. Ṣāpūn gibi yur, șāpūn otı dahı dèrler.

Kethac: Süpürge otı ve kara boya.

Kerkem: Za ferān ve bir dārūdur ve zerde-çūbdur.

Kerkemān: Kara yonca.

Kerūmān: Bir dürlü dikendür deve yèr.

Kerve: Tere toḥm ve tere deddükleri otdur.

Kerevye: Yandaḳ otı ki tāzesinden türșī èderler kebere gibi dẻrler.

$[2 \mathrm{~b}]$

Geza': Uşaḳ dẻdükleri dārū ki edviyedendür.

Kez-engübīn: Ve kezenbū ve kejbī ki havādan yagaar bellūt ag̉acı üzerine.

Kizvān: Bir otdur ki kokusı ve dadı tūrunc dadına benzer. Kabı tūrunc kabı gibi olur. Gökçedür. Uvacık yapragì

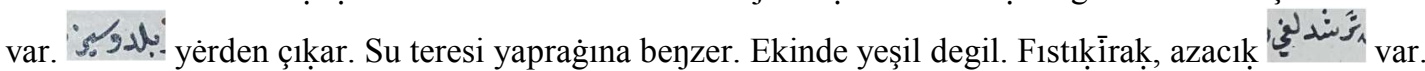

Ekiştec: Bir nev ${ }^{c}$ aḳ mantardur ki ba ${ }^{c} \dot{z} ı$ yèrlerde müreyr dèrler.

Kişmiş: Çekirdeksiz, uvacıḳ, ḳurı üzümdür.

Kişnīz ve kişnic: Ve kișniș ve küzbere dahı dèrler bir ḥoș kohulu toḥmdur. Ekșer bug̉day içinde olur, biter. habbü’rreşād dahı dèrler.

Kemāșīi: Bir nev` żamkdur. Çāvșīre beyzer, Hindistān'dan gelür. Ba īid degil ki çāvsīir-i hindī ola.

Kendir: Günlük ki tütsi èderler.

Kendülāş: 'Arab kürāş dërler bir otdur ki ana yebdūn dèrler.

Küncīd: Șūsām 
Gendāne: Kendīr ki ma 'cūfdur.

Keneştū: Bir otdur ki ana anderūd dèrler, yẻmişdür. 'Arabça maḥleb dèrler ve çogiana dahı̆ dèrler.

Gendānā: Bellü bir ot adıdur ki 'Arabça kürrās dèrler.

Gezmī: Bir otdur ışhun cinsindendür.

Gezne: Iṣırgan otıdur.

Geşt: Bir otdur yẻre döşenür, birbirine șarmaşur. Rengi ḳızılraḳdur.

Kejā: Ḥūdarū dèrler bir otdur.

Gevest: Kāf-1 'Acem-ile 'Arab-1la ḥanțāl ki ḳarga düvlegi dẻrler gāayet de 'acıdur ve it ḥıyārı dèrler.

Kehc: Alıç yẻmişi ve butm yẻmişi ki ḳoca yẻmişi dẻrler ve çilek gibi țag̉larda biter yẻmişdür.

Kehiç: Dag erügi ve

Geyik: Ve keşe berre

Kerāne: Yandaḳ otı ve deve dikeni.

Gitī-ārāy: Bir güldür ki yapraḳları olur. Baṣra şehri cānibinde olur. Çoḳ zamān dökülmez ve kuruduḳdan ṣoyra esbāb ve kūmāș arasına ḳorlar ḥoș rāyiḥa vẻrür. Misk ü 'anber gibi rāyiḥa vẻrür ve 'ālem-ārāy daḩı dèrler.

Kūye: Buyan balı. 'Arabça ḳarbūs dẻrler, öksürüge nāfícürr.

Günlük: Ya'nī habbü’l-bān dèrler.

Kerevyā: Kemmūn dedükleri otdur.

Keşūr: 'Acem şahdāne dërler.

Köknār: Ḥaşhāaşdur dèrler.

Kenār: Kāf-1 ‘Arab-1la gülnār ag̉acı ki köknar dahı dèrler ve sedīre yẻmişi dèrler.

Kūber: Fülfül ya nī biber ki issi otdur ve baldırana ve çiçegine dahıı dèrler.

Gevz-gendüm: Ṣıġır mantarı dèdükleri otdur. Dāneciklerdür, nohūi gibi șaruya mā’ildür. 
[3a]

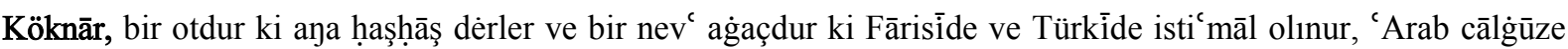
dèr.

Gāv-çeşm: Öküz gözi dėdükleri. 'Arap 'arār dèr. Șaru çiçek ki ṭabībler ḳatında behār dèmekle meşhūrdur.

Genūdān: Ve genūrāne. Kendir toḥmı ana șehdāne ma nāsınadur.

Künhān: Bir ag̉acun adıdur ki yapraġı șakızlı̣ ag̉acı yapraġına benzer, kokusı tütün kokusına benzer ve kūnhān dahı dèrler.

Kūper: Fülfül-dārū ki țabībler ḳatında ma rūf edviyedür.

Kūhencü’l-vec: Daġ yėmişi dèdükleri ki `Arabça zu'rūr dèrler.

Key-gūşne: Bere ot1.

Gīl-dārū: Eyreltü dẻdükleri ot ki tabībler katında serahs dẻmekle meșhūrdur.

Kāfūr: Bir dārū-yı ma'rūf ki Hindistān'dan gelür. Ag̉açdan mütereşşị evvelki çıkar gökçerek mă'-i kāfūr dèrler tonıcak bir niçe dürlü olur. Evlāsı Kayșūīiuür. Serendīb kıııssında bir yère mensūbdur ve bir dürlüsine kāfūr-1 rebbāḥi dèrler. Rebbāḥ, bir ulu şehre mensūbdur. Ġayet de aḳ olur. Ba żı̀lar dẻdükleri evvel bulan Rebbāḥ adlu bir pādişāh idi. Anunçün rebbāḥi dèdiler ve bir dürlüsi galīẓ ve kararak olur. Bir dürlüsi ag̉ac-1la ḳarışık olur. Bunlar

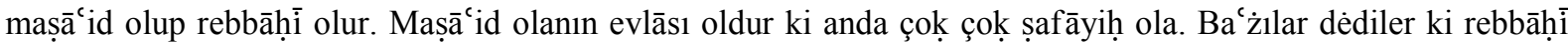
kayșūranuy mașācididür.

Gevz-giyāh: Ayrık otıdur.

Gerezü'l-gāar: Fındıḳdur.

Kūşād: Ve çıntıyānā dẻdükleri centiyāne dahı dẻrler otdur. Edviyedendür.

Köknār: Bir dürlü çam ag̉acıdur ki yėmişi fıstık gibi. Türkīde dahı köknar dẻrler.

Kevnīz: Fıstık ve Hindistān kozıdur.

Girdegān: Kọ.

Güyegü otı: Kekik otınun bir nev'idür, sa ${ }^{c}$ ter dahı dẻrler. Bosna lisānında çūbrā dèrler.

Kīkīr: Kerdeme isırg̉an toḥmına dèrler.

Gez: Ilġındur.

Kene: Esrār otıdur. 
Kīkīr: ‘Arabça cercīr dèrler ya nî̀ baḳılā-yı kīkīr dahı dèrler.

Gül-i bī-fermān: Bir ḳızılca çiçekdür çayırlarda biter.

Ketlīn-i ābīi Șu kerdemesi. 'Arab, cercīrü'l-māà dèrler bir otdur. Ḳaz ayagiı dahı derler.

Kiyek: 'Arab ṭ̣hāl dèr, 'Acem sīrsef dèr ḥār ve yābisdür.

Küzbere: Ve kişnic ve kişnīz ve kişniş dèrler, bārid ve yābisdür.

Gendüm: Buġday.

Göz ḳuyrugì: ‘Arab żenebü’l-çeşm dèr ḥabbü’s-selāṭin dahı dèrler.

Gömren: Deve țabanı otı dèrler hindū-şāh, naḥcüvān ve șahāḥ daḩı dẻrler.

Gül-i hủirì: Dèrler Mıṣır benekșesidür. Șebbūya dahı dèrler.

Kemhā: Dėdükleri otdur. Yapraġı dögüp șıracaya uralar eyüdür dèrler.

Gūş-1 bere: Ḳuzı ḳulaġı otıdur.

Keyş: Çam ag̉acıdur.

Kemā:

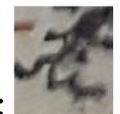

Kelūl: Burçak.

Kebest: Ḳarg̉a düvelegidür.

[3b]

Kāfūr-siperm: Ġubeyrān, feslegen dèdükleri otdur ki rengi ag̉ olur. Ețibbā ḳatında ma' rūfdur.

Kākiyān: 'Aṣbir toḥmı.

Kāvencek: Şīn-ḩyār ve tāze huıyār ve sebzevāt-1 bād-reng mánāsına.

Kāhū: Mārūl ve kök dahı dèrler. Būstānlarda biter. 'Arabça ḥass dèrler ve ṣāliḥa ag̉acına dahı dèrler.

Kīlīse: Ag̀u kundus dèdükleri ot.

Kābīle ve Kābīl: Dahıı dèrler, ma rūf bir otdur.

Ketvān: Katrāān.

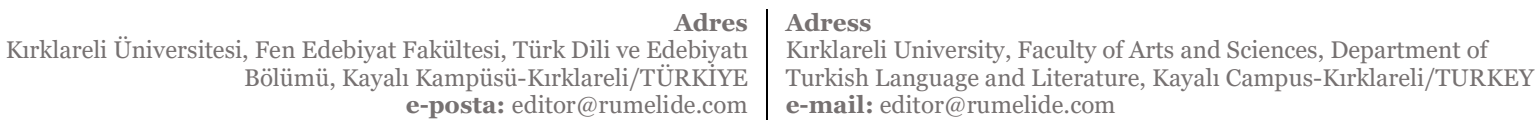


Kebūde: Sorḳun ve şemşīr ag̉acıdur.

Kebest: Ve kebestū ve kebeste ḥabb-1 ḥanțal dedükleri otdur. Aya ebū cehil ḳarpūzı dèrler. Acıdur, ag̉udur ki it ḥıyārına dahı̆ dèrler zīrā ki bu dahı it ḥıyārınuy bedelidür belki andan artuḳdur.

Kācīre: Ve kāzīre. 'Uṣ̂ūr dèdükleri otdur.

Kāginne: Ölgülük dẻdükleri böcekdür ki ag̉ulardandur. Ḳuduz dalayana yẻdürürler. 'Arabça zerrūc dèrler, cem èdüp zerārīc dèrler.

\section{[4a]}

Keder: Kādī ag̉acı ki țabībler ḳatında meşhūrdur.

Kirm-dāne: Kurd bağrı dẻdükleri ag̉acun yėmişidür.

Kedū: Ḳabaḳ ki ḳar` ma`nāsına.

Küjm: Gögem yėmişidür ki `Acem ḳūmūh dėdükleri dikendür.

Gezmāzek: Ve gezmāzū. Yılg̉un, ḳoz ag̉acı ki țabībler ḳatında 'azbe ve gejgāf dèmekle ma'rūfdur. 'Arabça gezmāzec dahı dèrler.

Kündüs: Ag̀u ḳundus dėdükleri ki țabībler ḳatında ma'rūfdur.

Gendīne: 'Arab kürrāz ve Türkī pırașa dèmekdür.

Kāmūn: Rāziyāne. Bosna lisānında morāc dẻmekle ma rūfdur.

Gelincik çiçegi: Bir ḳırmızı çiçekdür, tarlalarda olur. Bosna lisānında pūjūr dèrler ma'rūfdur.

Kīkiz: Isırg̉an toḥmına dèrler ve gezne dahı dèrler.

Kerinc: Çörek otıdur ve ḥabbü's-sevdā ve şūnīz dahıı dèrler.

Kūpel: Bābūnec dèdükleri otdur. Ba ${ }^{c} \grave{z} 1$ yèrlerde pāpādya dahı dèrler.

Gögündürük: Pazı kökidür ki ana çügündür dèrler şüvündür dahı dèrler.

Kekik otı: Ve güyegü otı dèrler. 'Arabça sa'ter dèrler. Bosna lisānında çūbrā dèrler.

Egir ot1: Ac1 ot ki aya 'Acem fejej dèr ve 'Arab vec dèr.

Kedi otı: Ki ana asārūn dèrler.

Kebīje: Cemīi lisānında ma 'rūf. Hูār ve yābisdür.

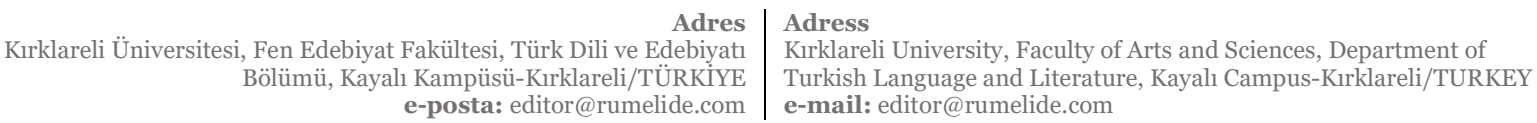


Kettān toḥm: Hārdur, ammā yübūsetde ve rațblıḳda mu`tedildür.

Germe: ‘Arab cercīi ve Fārisīide kīkīr dèr. Ḩār ve yābisdür.

Kesdāne: Ki aya 'Acem şāh-bellūt dèr. Ḩār ve yābisdür.

Kīrāz: Gülnār; ma 'rūfdur. Her lisānda gülnār dahı̆ dèrler.

Kemnūn: 'Arabīde zīre dẻrler. Ḩār ve yābisdür.

Güçle büken: Ki aya karga büken dèrler.

Keşūr: Fārisīde gezer, 'Arabīde cezer, Bosna lisānında anūḳa otı dèrler. Ḩār ve bāriddür.

Güneyik: 'Acem ḥaşḳ̄ḳ, 'Arab hindübā dèr.

Kelker: `Arabça ḳulkāsdur. Mu`tedildür.

Kūkşāre: 'Arabça çākḡūbredür. Ḩār ve raṭbdur.

Gülgen: Aġacı márūfdur.

Gil-i ermenī: ‘Arab țīnü’l-ermen dèr. Hāarr ve yābisdür.

Ketūr: 'Acem șehdāne ve 'Arab șehdānec dèr. Hār ve yābisdür.

Kemāyriyūs: Ṭabībler ḳatında meşhūrdur.

Kükürd: Nār-1 hażzāa ve 'aḳreb-i ḥacerü’n-nār dahı dèrler. Ma 'rūfdur.

Kemḥā yapraġı: Bir otdur dögüp șıracaya ursalar ḳurıdır, ḳıra ve tāze et bitüre.

Kūşād: Çıntıyāne dèdükleri otdur.

Kermetü’l-beyżā: Dërler bir otdur ki ana örengül dèrler.

Kermetü's-sevdā’’ Dėrler bir șarmașıḳdur kıızılca yėmişi olur.

[5a]

Kerdeme: Dërler bir otdur, tabībler katında ma 'rūfdur.

Kündüs: Dẻrler bir otdur. Türkçe kurtlu ot, Bosna lisānında çemrīka dèrler.

Kemāzeryūs: Kim Türkçe hamāzeryūn dẻrler. 
Kemāfītūus: Türkçe harb țutana dèrler.

Keșīrā: Eṭibbā ḳatında bir ma 'cūf otdur.

Kelem: Bir meşhūr otdur.

Gāv-zebān: Türkçe șı̣ııır dili dẻrler.

Kenger: Meşhūr bir dikendür.

Gülbetere: Deve dikenün bir nev'idür.

Gāvers: Daru. 'Arab duḥn dèr.

Kesḳin: Baldurı ḳara dẻdükleri otdur.

Küzberetü'l-ḳılāṭ:: Baldurı ḳaraya dahı dërler.

Küçük dāne: Behmen dèdükleri otdur.

Gezmāzec: Ve germāz ve 'azbe ve yılġun ag̉acıdur.

Kürünb: Dėrler bir otdur ḳunnebịṭ dahı dèrler bir ma rūf otdur.

\section{Faṣlü'l-fīi ḥarfi'l-lām}

Leylāk: Dẻrler bir ag̉açdur ki ana erg̉uvān ve ercüvān dahı dẻrler Fārisīdür.

Labața: Dẻrler bir otdur ki ana ebem gömeci dèrler. Bosna lisānında silez dẻmekle ma '́rūfdur.

Lāgiye: Südlügen dèdükleri otdur.

$[5 b]$

Lisānü'1-ḥamel: Sinirlü yaprag̀i.

Lūbiyā: Bögrülce dèdükleri dānedür.

Lisānü'l-'uṣfūr: Türkỉ ḳuş dili ag̉acına benûş dèrler.

Lisān-1 șevr: Ki ana ġāv-z[ebān] dèrler.

Laṣaf: Türkīde kebere dèrler.

Lüffāh: Dèrler bir otdur ki ana ḳurudan dèrler 'Acem şābīzek dèr ve hạ̄ılar otı dahı dèrler.

Lūn ve Lūnā: Kaya ḳorugìdur. 
Lapā: Pirinçdür.

Lāle-i kūhī: Şakāỳık çiçegine dèrler.

Lāle: Bir çiçekdür envā̄ 1 olur, meşhūrdur.

Lahana: Cemī dilde ma ${ }^{c}$ rūfdur.

Lābada: Ma rūfdur, it ḳulag̀ı dèmekle meşhūrdur.

Lūḳās: tabībler ḳatında meşhūrdur, otdur.

Lìmūn: Cemī' dilde ma' rūfdur. 'Arapça böyle dèr.

Leblāb: Dẻrler Fārisī tạạ dèü dèrler ve sezt daḩı dèler Türkỉ ḳumla ve ṣandaluḳ dahı dèrler. Ḥekimler ḳatında ma'rūfdur.

Lihyetü’t-teys: Bir otdur ana pambuḳluḳ dèrler. Ekșer bayırlarda olur lādān anuy üzerine yag̉ar. Ḳızıl gibi çiçegi olur. Ortası șaruca ba ${ }^{c} \dot{z} ı$ yẻrlerde ak çiçeklü olur, ortası șaruca yeşil yapraḳlu olur. Ḳış, yaz durur. Alçacık ag̉açları olur anuy kökinde lı̣̣yetü’t-teys ot bulınur. Her kökinde bulunmaz, yigirmi otuz kökinde bir bulınur. Yā bulunmaz evvel bahārda olur. Ol dahı̆ yag̉murluḳ olıcak bir güzel çiçek garāyibdür. Ḳuruyıcak ḳızarur evvelki şeklinde kalmaz.

Lāle-i deştī: Gelincik çiçegi. 'Arapça şakāyı̣[u’n]-nu'mān dèrler. Lāle-i kūhī dahıı dèrler.

Lebnīc: Ḥıyār ag̉acına benzer bir ag̉açdur. Lebūt, dahı dërler. Lepûs dahı dẻrler.

Lahtīş: Ve hīīi dèrler. Şebbōy dèdükleri çiçekdür ki gice ile ḳoḳar.

Laḥ: Ḥaṣır otı, lūḥ dahı dèrler.

Lāden: Her dilde ma' rūfdur.

[6a]

Levz: Bādemdür.

Lift: Șalgam.

Lehlab: Bādıncān. Bādıngān, ba ż̇̀lar dèdiler.

Laplapī: Neçder, dèrler bir otdur ve nohūda dahı̆ dèrler.

\section{Faṣlü'l-fīi ḥarfi'l-mīm}

Mürr-i șāfī: Bir adı defne yẻmişi dèrler. Ḩār u yābisdür. 
Mārūl: ‘Acem kāhū dèr, 'Arap ḥașinn dèr. Bārid ü raṭbdur.

Māş: Türkỉ mürdük ve karaca bögrülce dèrler. Bosna lisānında ġırah dẻrler ma ${ }^{c}$ rūfdur. Bürūdetde, ruṭūbetde mu'tedildür.

Maḥmūde: Fārisīde saḳmūnādur. Bosna lisānında emlec dẻrler. İki nev`c olur südi çıḳar. Bir nev ' yapraḳları gök olur șaruya māyildür, balı̣̣ ag̉usıdur. Ancaḳ maḳbūl olanı yapraḳları gök ola.

Māmîşā: Dẻrler bir otdur hilāliye daḩı dèrler. Șaru ṣuyı olur. Boşnakçça rūụūpāṣ dẻrler.

Merah: Çam ag̉acına dẻrler.

Māzeryūn: Bir adı ḳalye dẻrler. Bir adı dahı kündüsdür. Bosna lisānında çamrīḳa dẻrler.

Meymūn: Yarpuz otıdur.

Māderyūn: Ceşer dèdükleri otdur.

Mār-çūpe: Bir otdur ki șaru çiçegi olur ve dahı bir ag̉açdur.

Mārḳaşişā: Üzer otı dèrler bir otdur.

Māh-1 pervīn: Cedvār ki mu 'teber dārūdur. Tiryāḳlardandur, ag̉uları def ${ }^{c}$ èder ve bîş dèrler bir otdur cedvārla hebce biter. Her kişi ikisinden birbirinden fark èdemez.

Mencūşe: Çetük otınuy bir nev'idür.

Merzengūş: Ak gül, çigdem ve gözlük otıdur.

Mertek: Merūşīle dẻdükleri otdur ve 'abreter dahı dèrler.

Mentūr: Bir çiçekdür.

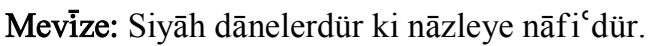

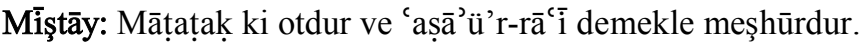

Mī`a: Kara günlük.

Müşk-pīd: Sorg̉un çiçegidür ki 'araḳın çıḳarurlar.

[6b]

Māhī-zehrec: Türkçe būsīi ve māhber-herc ve māh-tehrec ve balıḳ ag̉usı dahı dèrler ve ṣığıı ḳuyruġı dẻrler. Bosna lisānında dīvizzma dèrler. 
Mantar: 'Acem ekāriș dèr, Türkī tọalan.

Mencū: Mercimek. 'Acem enze dèr, 'Arab 'ades dèr.

Ma denūs: 'Acem bād-ro dèr ve ba żżlar tere-i hororasānī dèr.

Maḥmūr çiçegi: Ki ana beg börki dẻrler.

Mıṣır baḳlası: Dėrler bir otdur. Dārūdur ve termiye dahı dẻrler.

Mersīn ag̉acı: Ki 'Arap ās dèr, hoş ḳoḥulu yapraḳdur. Bir ag̉acun yapraġıdur. Yapraḳları yaz ve ḳış durur, yeşildür.

Muhalliṣa: Dẻrler bir otdur. țabībler ḳatında meşhūrdur.

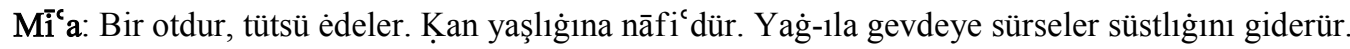

Māzū: Ma rūfdur.

Maștakī: Ki 'Acem ilk dèr, 'Arap maștakạan dèr meşhūrdur.

Mişmiş: Ki Türkī muşmūla dẻrler ve zerdālūya dèrler.

Mā'ü'l-ḳarāṭ̂̄n: țabībler ḳatında ma rūfdur.

Mevzek: Ețibbā beyninde ma rūfdur.

Meryem ana eli: Bir otdur márūfdur.

Muḳl: Ebū cehil ḳarpūzı dèrler bir otdur. țabībler ḳatında meşhūrdur.

Mevīzek: Ḳuru üzüme dèrler.

Müşk-i türkmān: Ṭopalaḳ.

Muḳl: Ebū cehil ḳarpuzı ve çivīd yaprag̀ı.

Mülk: Burçaḳ dèdükleri hubūbātdandur. Güşne dahı dèrler.

Melīk: Ebem gömeci dėdükleri otdur.

Mūḳulūn: İklīlü’l-melik dèrler. țabībler ḳatında ma 'rūfdur. Bosna lisānında melik-ḳūk dèrler.

Mār-cūbe: Dėrler bir otdur her-cūbe dahı dèrler helyūn dahı dërler.

\section{[7a]}

Mugaaylān dikeni: Ma'rūfdur.

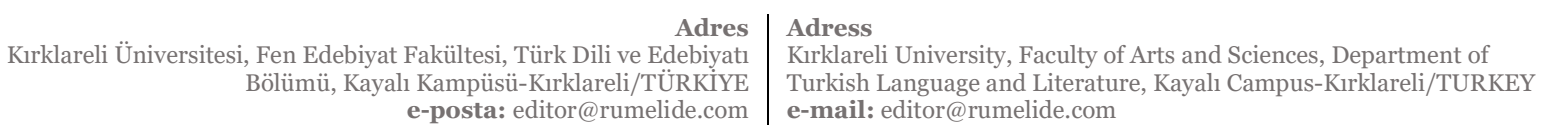


Mendīk: ‘Acem kārşim dèr, bir otdur. tabībler ḳatında ma ' rūfdur.

Mürver: Dẻrler bir aġaçdur. Bahārınun șuyı tașaya ve gönül dönmesine nāfi`dür.

Mürr-i Mekkī: Dėrler bir otdur. țabībler katında ma 'rūfdur.

Merțūb: Ețibbā ḳatında ma' rūfdur.

Merzengūș: Dėrler bir ma'rūf otdur.

Māmişsā: Dèrler bir otdur. Ețibbā ḳatında ma rūfdur.

Maġsūl: Dérler bir otdur. țabībler ḳatında ma rūfdur.

Mahleb: Ețibbā ḳatında anzurūt daḩı dèrler. Çoġana daḩı dẻrler. Meşhūr bir otdur.

Misk-i rūmī: Meşhūr, má rūf bir otdur. Misk gibi ḳoḳar.

Mī‘a-i sāyile: Kim Türkçe zıġla dèrler. Ḳara günlük revġānıdur. Ḳoyu bal gibi merāhim olur. Ḥūb rāyiḥası olur.

Meryem yapraġı: Bir otdur. Güneyik çiçegi dahı̆ dèrler, ḥoşça ḳoḳar.

Marsama: Dèrler ve ba ċ̇̇lar tamām sisenber dahı dèrler.

Mürāsim: Dėrler bir otdur. Ḥoşça rāyiḥası olur. Boşnakça kāāūper dẻrler.

Merāre: Bir ' acı otdur ki ana üştüve dahı dèrler.

Mūyḥūşe: Sünbül.

Mekke ayrugì: țabībler ḳatında meşhūrdur. Ḥadel ve hafez dẻrler.

Mīve-i gez: Ilġın yèmişine dèrler. [7b] 'Arab țarf dèr. Hูār u yābisdür.

Mașīl: Kavundur. Bāriddür.

Māṭațak: dèrler bir otdur. Bersiyān dahı dèrler. țabībler ḳatında 'așāfīir ve 'aṣā'ü'r-rāâ i dahı dèrler.

Merdūd: Bir otdur. Zagiin dahı dèrler, ma rūfdur.

Ma rūża: Bir otdur. Șarulık otı dèler. Ba '̇̇̇lar zerde-çūbdur dèrler.

Menūk: Dërler bir otdur. Gāsū ve gāsmūy dahı̉ dèrler.

\section{Faṣlü'l-fī-ḥarfi'l-nūn}

Nohūd: Meşhūrdur.

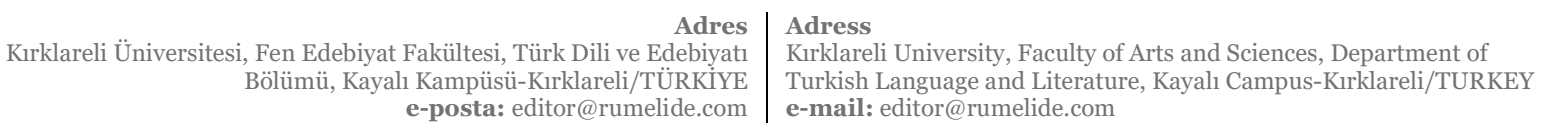


Na'ne: Buzīne dahı dèrler.

Nưmān: Ma rūfdur. Bosna lisānında șarı yabalan dèrler.

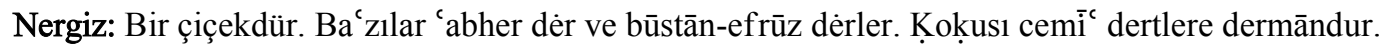

Nişādır: Ma'rūfdur.

Nīlūfer: tabībler ḳatında ma 'rūfdur.

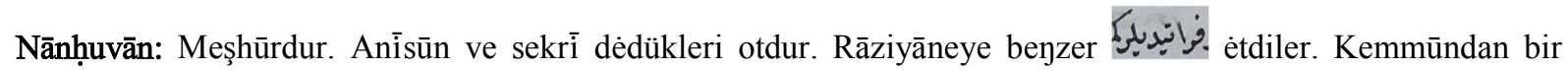
nev' dür.

Nāb-1 ‘ gurāb: Eyreltü otıdur.

Necel: Timür boḳı dërler.

Nelk: Ṭag erigine dèrler.

Nesk: Bir cins mercimekdür.

Nesterūn: Ve nestūn. Nesrīn, çiçekdür. Ak żanbaḳ dèrler.

Nāz-būy: Feslegen.

Nāk: Mentek otı.

Nahc: Sübürge otı ve 1lg̉un ag̉ac1.

Neresk: Mercimek dèmekdür.

Neştek: Enār ag̉acı ve ḩatel ag̉acı ve terḥūn ve çam ag̉acı.

Nīrās: Tezyāze dèrler bir otdur.

Naḥlegūn: Zūk ag̉acı.

Neltehīi: Kạtır kuyrugiı dėdükleri otdur. Mư tedildür.

Nebūş: Bir ag̉açdur. Dişbudaḳ dẻrler ve 'Arab bāneḳış dèr, mā’’, ṣuyı çıḳar meşhūrdur.

Nimişk: Buṭm dèrler ve hạabetü'l-ḥașra dèrler bir otdur.

Nābīn: Dẻrler, bag̉ ṣog̉anı dèrler.

Nārdīn: Dèrler, sünbül-i rūmī dèrler. 
Nāk: Misk otına dèrler.

Nānḥuvān: Meşhūrdur. Anīsūn ve sekrī dèdükleri otdur.

[8a]

Nīfe: Estūr ag̉acidur.

Neşk: 'Acem nūj dèr ve nūş çam ag̉acıdur.

Nicle: Bir otdur ki ana toḥmekan dèrler ve baklatü’l-ḥamakā dahı dèrler.

Nahcüvānī: Hindū-şāh dẻdükleri otdur.

Nār: Ki enār dahıı dèrler, meşhūrdur.

Nesīm: Bir meşhūr otdur. Ețibbā ḳatında ma'rūfdur.

Natrūn: Dèrler bir ma' rūf otdur.

Necīl: Ayrıḳ otı dėmekdür ve necm dahı dèrler. Bosna lisānında pirevān dèrler.

Nāc: Çam ag̉acı ya'nī serv ag̉acı.

Nār-post: Karanfīil. Ḥoş ḳoḥulu odundur.

Nārcīl: Hindistān kozı.

Nār-ḥūn ve nāhūū: Gülnār çiçegi.

Nārdīn: Sünbül-i rūmī dèdükleri çiçekdür.

Nār-misk: Ḳızılcık. Fārisīde miskü’r-rummān, Hindīler aḳmāc rummān dèr. Hindīdür. Küçürek enāra beyzer ki çiçegi düşmiş ola. Hộ rāyiḥası olur. Eyüsi oldur ki ḳızıl olup aḳlığa mā̉il ola.

Nārvan: Kara ag̉aç ki uzun olur ve tarhūn dẻdükleri ag̉açdur.

Nāzīden: Çam ag̉acı ve serv ag̉acı ve çemşīr ag̉acı ve serv ag̉acına beyzer bir ag̉açdur. Yèmişine çālgūre dèrler. Bādem ile yèrler. Her tabībe ma'rūfdur.

[8b]

\section{Fașlü'l-fī-harfi'l-vāv}

Vīşe: Bir nev' șarmaşıkdur ki ạa 'Acem ḳıṣuṣ dèr. Türkī yoḥsul urg̉anı dèrler.

Vesīme: Rāstık țaşıdur. Rāsuht dahıı dẻrler.

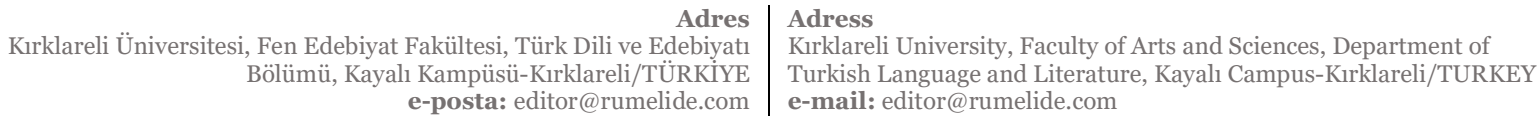


Vuşak: Ki 'Acem kezag̀ dèr bir meşhūr dārūdur ki edviyedendür.

Vertāc: ‘Arab ḥubbār(z)ì dèr.

Vetūle: Güneyik çiçegi dahı dèr. 'Acem ḥod-perest dèr. Türkỉ eben gömeci dèdükleri otdur.

Vec: Egir otıdur. Vej dahı dèrler.

Veyl otı: 'Arab hasṣṣu’l-ḥımār, 'Acem kāhū-yı har dèr. țabībler ḳatında ma 'rūfdur.

Vīşne: Dėdükleri yẻmiş, má rūfdur.

Verd: Güldür.

Vaḳne: Bir otdur ki dāne çādırı daḩı dèrler.

Vezc: Göz otı.

Vezgaşt: Bir otdur. Ețibbā ḳatında ma rūfdur.

Verkā: Karamuḳ dẻrler. Siyāh dānecıklar vardur, bug̉day içinde biter.

Vekmeşek: Șaḳız ag̉acı ki cedene dẻrler. țabībler ḥabbetü'l-ḥażrā’’ dèrler.

Vende: Kerdeme dèdükleri otdur.

Ve serkile: Şāhtere ve şayțarac dahı dèrler. Ma'rūfdur.

\section{Faṣlü'l-fī harfi'l-hā'}

Hikendū: Bir nev otdur. Rebbāhī cinsindendür.

[9a]

Hüzbe: Çigdem dèdükleri bahārdur.

Hindū-şāh: Bir otdur nahcüvānī daḩı dèrler.

Hezme: Bir otdur ki aya 'Acem heykel dèr ve 'Arab cehle dèr.

Helyūn: Bir otdur ki mār-cūbe dèrler ki ‘āmme tahrīf èdüp her-cūbe dèrler.

Hindibā: tabībler ḳatında meşhūrdur. Ba żı̇lar kāsnī dahı dèrler.

Hābdetūn: Kim ana hükemā türbūs dërler. İshāle ve ḳana ve zerve yumurda ile ve bal-1la yėdürseler nāfí dür.

Hāvuc: Ac-1la pişmiş yẻse āvāzı açıla. 
Hīzme: Bir nev`şalġamdur ki ana dag̉ şalġamı dèrler.

Hīrun: Bir adı ḳıçıdur. Ma rūfufdur.

Helīle ve belīle: Ve helbāk dahı dèrler. țabībler ḳatında meşhūrdur.

Hīl-i bevvā: Kạạūle-i ṣig̀ārdur. Hāl dahıı dèrler.

Hilāliye: Dẻrler bir otdur. Șaru șuyı olur, za ferān gibi. Türkçe șarulıg otı dẻrler. Bac żılar māmişā nev indendür. Südi göze çekerler, nūrın ġāyet ziyāde èder. Gözi acıdur. Ba ż̇̇lar ḳanlucadur dèrler.

Heyyū fārīkūn: Dėdükleri otdur. Her yèrde bulınur.

Her dem tāze: Tāze dèrler bir ot olur. Yaz ve ḳış durur ve her yapraġı üzerinde ḳırmızı mercān gibi dāneleri olup țabībler ḳatında maḳbūldür.

[9b]

Herjefdek: Kunduz țaşaġı dërler bir otdur. Çayırlarda biter.

Hezār-dāne: țabībler ḳatında bir ma rūf otdur.

Hezār-ṣıfend: Bir dārūdur. Ḥar-dār dèrler.

Heykele: Haykele dèrler bir otdur.

Hindüvāne: Kāārpūz.

Hūşì: Çog̉an otıdur.

Hünām otı: Dėrler bir otdur. Ekșer çaġan yėrlerde olur. Yapraġı yonca yapraġına benzer.

Heyşebīn: 'Arab 'acbe dèrler Bosna lisānında manūğlad dèrler.

Hindistān kozı: Bir adı nārçīldür.

Hevānte: Bir otdur yẻllere ve diz ag̉rısına andız ile ḳaynadalar, ısıcakla içeler, derleye, nāfídür.

Hemsūd: Kııılcık.

\section{Faṣlü'l-fī ḥarfi'l-yā}

Yāsemīn: Meşhūr bir çiçekdür.

Yonca: Fārisīde sepist ve boy dèrler. 'Arabīde ratbe dèrler. Ḥār u raṭbdur.

Yandaḳ: Kim ana üştür-gāāz dèrler bir otdur. Ḩār u yābisdür.

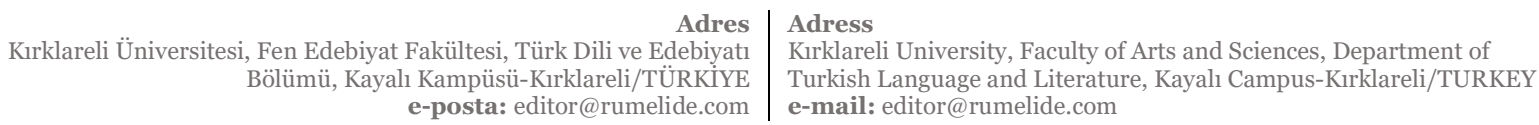


Yèr mürveri: Ki ana sulțān otı dẻrler. Bosnaca hạapțūnye dèrler.

Yarpuz: Yabān na'nesi. Meşhūrdur.

Yebdūn: Bir otdur ki 'Acem gendūlāş dèr, 'Arab [10a] kürrāṣ dahı dèr. Türkī gendānā dèrler.

Yerniyān: Baḳam ag̉acıdur.

Yāpezī: Persiyāvșān dèrler. 'Acem ‘Arab kesḳīn-i bir dèr. Türkỉ baldırı ḳara dèrler bir otdur.

Yoḥsul urgaanı: Dẻrler bir dürlü șarmaşıḳdur. 'Acem vişsne, 'Arab ḳısūs dèr.

Yalıncah: ' $\bar{U} d$ ag̉acına dèrler.

Yılġun: Bir ag̉açdur, ma rūfdur. 'Azbe dahı dèrler 'arī dahı dèrler.

Y1lan yaṣdugì: Bir otdur öksürüge ve nāzleye balla ma cūn èdüp yėse şifā bula.

Yapışgan: Bosna lisānında çiçeḳa dẻrler ma 'cūfdur.

Yerbe: țabībler ḳatında ma' rūfdur.

Yarasa otı: Meşhūrdur.

Yoṣuy: 'Arab cag̉r-ābe dèr, 'Acem țuhlüb dèr.

Yabān turpı: țabībler ḳatında ma 'cūfdur.

Yezġand: Tetr dẻdükleri otdur ki toḥm-1 summāk olur.

Yebrūcü’ṣ-șanem: Bir otdur. 'Acem istereng dèr. Çīn vilāyetinde çoḳ olur. Ādem șıfatludur. Eli, ayaġı, başı, gözi, kulaġı olur. Bögürtlen yapraġı gibi yapraġı olur.

Yerșūn: Dẻrler bir otdur ki ana uşne dèrler ag̉açlar üzerinde biter. Ak aḳ, șaçak șaçaḳ, tel tel aşag̉a șarḳar. țabībler şeybetü'l- 'acūr dèmekle meşhūrdur. Bosna lisānında ve Türkīde imel ve imele dahı dèrler.

Yabān șoġanı: Ki ana [10b] bülbūs dèrler.

Yevşāa: 'Acem derheme ve derhene dahı dèrler bir meşhūr otdur.

Yabān țorak otı: Dẻrler bir otdur ki ana 'Acem dīnārūye ve çördük dahı̀ dẻrler.

Yüzerlik: Ma' rūfdur.

Yențāfīiūn: Beș parmaḳ dèdükleri otdur. Ṭag̉ yarpuzı dahı dèrler. 
Yılan boncuġı: Dërler. Çüçük mühre gibidür. Dejiz kenārında bulınur. Bosna lisānında ḳuhçüçe dèrler. Edviye[ye] girer ot degildür. Böcek ḳabıdur.

Yemil otı: Dẻrler bir ot olur. Șāmaryūmā dahı dèrler. Anun erkegi dișisi olur. Ḥabbü'l-mülūk gibi üçer dāne bir yẻrde bitişmiş gibi biter. Degirmi şekilli sivrice yapraḳları biter. Güneşle bile țolanur, yapraḳları güneșe ḳarşu döner, güneyik çiçegi gibi. Bu otuy șuyunı neye degerse lācüverd reng gibi boyar. Kāg̀ıda ve ạ̣ bẻze dürtseler lācüverd gibi reng èder.

Yabān ṣarımsaġı: Kim sukūrdiyūn dèrler.

Yelimi: Dërler bir mübārek otdur.

Yārābe: Şalġam.

Yezġand: Tetrī dėdükleri agaaçdur ki toḥmı șummāḳ olur.

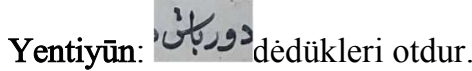

Yelā: Enḳardiyā dẻdükleri dārūdur.

Yaḳțin: Kabak.

Yentūḥa: Bir otdur [11a] bāgūrī dahı dèrler.

Yabān: Karanfīildür.

\section{Faṣl fī żamāyiri'l-insān ve țabāyi uhum}

Bu bābda żamāīr-i insānı ve țabāyi ${ }^{\text {i } i ~ b e y a ̄ n ~ e ̇ d e l u ̈ m . ~ I ̇ m d i ~ b i l g i l ~ k i ~ a ̄ d e m u ̈ y ~ s u ̄ r e t i n e ~ n a z ̣ a r ~ e ̀ t d u ̈ g u ̈ n ~ g i b i ~ ' a n a ̄ s ̣ ı r u y ~}$ kanġısına mensūbdur bilmek gerekdür.

Demevī ādemüy 'alāmeti oldur ki yüzi ḳızıl ve boynı țamarları dolu ve lu'ābı țatlu ve faṣd ve hacāmet yẻrleri giciye ve beden ḥamāmdan çıḳmış gibi ḳızıl ve issi ola.

Șafravī ādemün beyzi șarı ve ag̉zı acı ola ve kurı olur. Yübūseti ve susuzluġı galib ola. Ve gözleri șaruya mā’il ola.

Balġamī ādemün 'alāmeti oldur ki teni aḳ ve țamarları âheste āheste ḥareket ėdüp kendi kāhil ola ve çoḳ uyuya.

Sevdāvī ādemün 'alāmeti oldur ki levni esmer ola ve benzi ṣolmışca ve bedeni șiyāḥ ola. Dā’imā tefekkürden ḥālī olmaya. Ve ekșer zamānda gam-nāk ola. Güz faṣlında sevdā gālib ola.

Ķan galebesinden beden nā-ḩoş ola ve der çıḳmaḳ belüre ve sıtma gibi belürse muttaṣıl ola. berd ve ola, nevbet olmaya ve șovuk havada rāhat ola. 
Safra galebesinden țamarları tìz tīz ata ve isitme katı ola ve yandurıcı ola. Sıtmadan öydin ditreye ve bevli rengi șaru ola.

Balġam ġalebesinden ġāyetle ag̉ırlık bașa ve bevli rengi aḳ ola.

Sevdā gaalebesi tīzlikden gāalib olur ve güz fașlında ziyāde olur. Ve revnaḳı ḳızıllıg̉a ve yaşıllıg̉a meyl ėde.

\section{Bu faṣl ba ż̀ hastalıḳların esāmīlerin [11b] beyān èder.}

Bir ḥekīm her maraż ve her ḥastalığın ki ismin bilmese ana dahı 'ilāc ètmek bilmez ve ana hekīm dènilmez. Zìrā maraẓa göre devālar bulur ve 'ilāc olınur. İmdi insānda niçe bị hastalık vardur, Allāh'dan gaayrı kimse bilmez. Ve 'ilāc ètmege bilmez hekīm Allāh'dur. Ancak Allāhu Te āalā insānı sebeb ve illet eyledi. Her şey’den bir zerre, deryādan nīm-ḳaṭre irādet-i cüz’ìye vèrdi, kullarına bildürdi. Binde birin diyevüz. Ol esāmīler bunlardur ki żikr olinur.

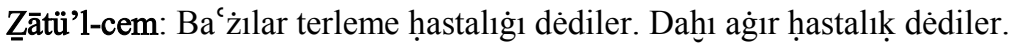

Tuḥme șayrulı̀g: Bir marażdur ki mi dede hạ̄ṣıl olur. Ṭa ām fāsid olup bog̉az ile burun arasında dumag̉u gibi bir 'illet tuḥmeden ḥāṣıl olur. 'Acem ḥalāşime dèr.

Sersām: Dėrler bir marażdur. 'Acem țabībleri serḥas dèrler. Dimāġun berdesi şişer șamurdayup èdüp söyler.

Sancu: 'Acem ețibbā bürniş̧ dèr, 'Arab hüükemāsı maġż dèrler.

Teb: Sitma dèdükleri marażdur.

Ḥukka: Öksürük marażıdur.

Çiçek: Dẻdükleri maraż ki 'Acem eṭibbāsı ana hāriş dèr, 'Arab hịkke dẻr.

Sersām: Devāsı baş ag̉rısındadur. Sersām iki dürlüdür. Birisi oldur kim anun māddesi șafrā-yı hāliṣ ola ve biri șafrā-yı kātīle ḳarıșmışı ola ve gaalebe-i ḳanuy ola. Ammā ol ki șafrā-yı hāliṣde ola 'alāmet oldur ki anun issi sitma ve uyḳusuzluk ola. Ve beyhūde sözler söyleye ve șuṣaya ve ag̉zı kurı ve acı ola. Beyzi șarı ve dili iri ola.

‘ìlāc: Ak ṣandal gülāb ile ezeler. Azacık kāfūr ve sirke țamzurup koḳudalar. Gögsine dürteler. Nāfi` ola.

Yėnür Baş: Dėrler bir marażdur. 'Acem ețibbāsı ḥūre dèrler, 'Arab ākile dèr.

Pelime ve Öksürük: Bir marażdur. 'Acem sürf dèr ve `Arab ‘alīl ve süfr dahı dèrler.

Uyuz 'illeti: 'Acem ețibbāsı kerū ve 'Arab cereb dèr.

Ḳızamuk: Marażına 'Acem ețibbāsı sürḥ-şere dèr, 'Arab ḥaṣbe dèr.

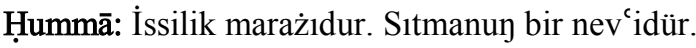

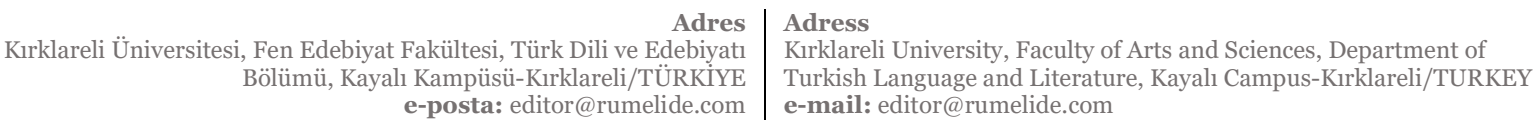


Yeraḳān: Șarılık marażıdur.

Ḥafạān: Yürek oynamasıdur.

Sigil: Ki gövdede çıḳar. 'Acem ețibbāsı gendeme dèr ve 'Arab șülūl dèr. Cem èdüp sāilīl dèrler. țabībler ḳatında bu ism-ile ma' rūfdur.

Yılancık: Dėrler bir marażdur ki 'Acem eṭibbāsı sürḥ-bād dèrler ve 'Arab eṭibbāsı ḥumre dèmekle meşhūrdur.

Temregü: 'Acem ețibbāsı beryūn dèr.

Kurdeşeni: Dèrler bir marażdur ki 'Acem țabībleri büșterem dèrler, 'Arab eṭibbāsı șerā dèmekle ma'rūfdur. Sūğrab dahı dèrler.

Şüşī ve verem: Marażına 'Acem ețibbāsı ammās dèr, 'Arab fakḥa dèr.

Ur 'illeti: Bir marażdur ki ana'Acem ețibbāsı ḥacş dèr, 'Arab țabībler sal'a dèr. Ādemün gövdesinde çıkar. Bādıncān ve karpūz denlü olur. Hīç ag̉rımaz.

Demegü: 'İlletine 'Acem gerīzend dèr. Beryūn dahı dèrler. 'Arab eṭibbāsı ḳabār dèmekle ma 'rūfdur.

Nıkrīis: Ayaḳlar aşag̉asında şişer ve 'ulmak yẻrleri ag̉ırur.

'Irḳünn-nisā’: [12b] Ol dahıı bir marażdur. Ayaḳların țopuḳdan aşag̉ası aġırur ve 'ulmaḳlar aġırur.

Baraṣ: Göz çevresi hastalığıdur.

Behak: Dahı gözün çevresinün țaşrasında olur. İki nevdür. Biri aḳ behak ve biri ḳara behaḳ dèrler.

Hanāzīr: Șıraca dėdükleri marażdur.

Şaḳāk: El ve ayak yarılup çatlanmasına dèrler.

Șar ${ }^{c}$ Cin dutdugì $1{ }^{c}$ illetdür.

Bevāṣīr: Mayāsıl daḩı dẻrler. İki nev'dür. Biri rīh-i bevāṣīr, biri bevāṣīrdür.

Ra`şe: El ve ayaḳ ditremesine dèrler.

Șudāc: Baş ag̉rısına dèrler. 'Acem ețibbāsı kātūde dèrler.

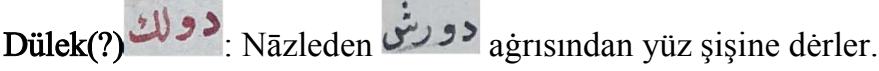

Zātü'l-cenb: Dėrler bir marażdur ki eyegü ag̉rısıdur.

Zātü’r-rīe: Öyken ag̉rısı. Sinirleri bozulmaḳ dėrler.

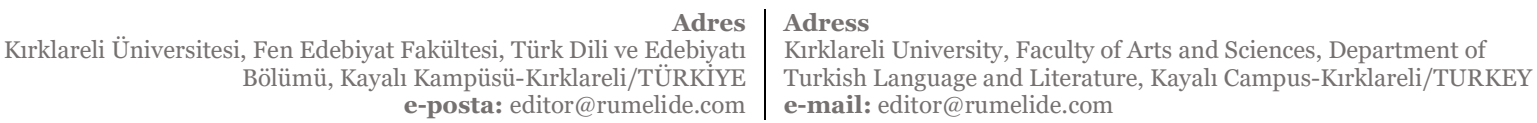


Meșāne renci: Ana dèrler ki sidügi dutulı gelür. Ve damla damla, buruyı buruyı, yaḳa yaḳa gelür.

Vec ${ }^{c}-i$ mefāṣıl: Ya $Y$ ni bendükşeler ag̉rısına dèrler.

$\mathrm{Sa}^{c}$ fe: Dėrler bir marażdur. Ufacık yaşıl bir çuḳurcıḳlar ve yaracıḳlar olur.

Bād-1 şenām(?) بَ: Bir marażdur ki țuzlı balġamdan hạậıl olur.

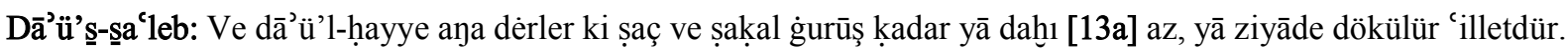

Faṣād: Ḳan almaḳdan bir yẻri ag̉rısı.

Ögrüge: Dėrler bir marażdur ki aya șıraca dẻrler. İnsānun sünüginde olur. Bẻl ag̉rısına dahı dẻrler. Eger ag̉rı ögrüge süyüginde olursa bel ag̉rısı dẻrler. Eger ayaḳlarda olursa nıḳrīs dèrler. Eger yan başlarında olursa yā dizde, yā topugaa degin inerse ana 'irḳu'n-nisā' dèrler.

Dā’ü’ṣ-șa‘leb: Bir marażdur. İnsānun vücūdında delik delik yaralar olur ve içinde diri ḳıl hạậll olur.

Şaḳiḳa: Baş ağrısınuy bir nev'idür ya nī şaḳaḳlar ag̉rısı dèmek olur.

Şeb-kūr: Bir marażdur göze ḳara șu iner ki ana tavuḳ ḳarası dahıı dẻrler.

Rịh: Dėrler bir marażdur. Yèller vücūdında ve yüreginde hạașıl olur.

İstiskāa: Bir marażdur ki üç dürlü olur. Birine istiskāâ-yı țablì dèrler ki ādemün ḳarnı büyür, hāmile 'avrat olur ve barmaġını batırsan ḥamīre batar gibi bata, el ursan dāvul gibi öter. Ve birisine istisḳā-yı ziḳi dẻrler. Bu dah̆ı et-ile deri arasında bir șarı irinlü sudur. Ḳarnı ve ḳasıġı dutar. Ve birisine istisḳā-yı lạ̣mì dèrler. Bunlaruy her birisinüy tedbīi başḳa başḳadur.

Firenk marażı: [13b] Ma 'cūfdur.

Cereb-i Firenk: Ya'nī Firenk uyuzı el-'iyāz̄u billāhi bir marażdur.

Cüzāam: Bir rencdür ki dükeli ten ḳaşınur. El- 'iyāžu billāhi bir marażdur kim balġamuy gaalīz ḩılṭı galebesinden ḥāṣıl olur yāhūd ḥatun ḥayżdan arınmadın cimāe ètmek ādemüy menīsi ol ḥayż ḳanıyla ḳarışur. Ol menīden ḥāṣıl olan evlād cüzāàm olmag̉a er bahāne ister.

Ḳ̄ūlunc: Dėrler bir marażdur ki tamām nihāyetin bulmış bir süddedür ki dimāġun toḥuyġaların (?)

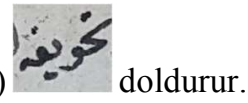

Felc: Dahı bögürtedür. Dimāgag rūḥ nüfūr èdecek yollarında daġılup münāḳīz-i südde èdüp āc żānun ḥüsn ü hareketin mu'aț̣al kılur.

Ṭalaḳ: Daḩı bir marażdur ki ṣuyı vaḳitsiz çoḳ içmekden ḥāṣıl olur.

Selesü'l-bevl: Dėrler bir marażdur. Șu yolı dutmaz olur. 
Verem: Bir marażdur. Ve żīku’n-nefes ve öksürük bunlar gögüsde olur.

Bevāṣīr: On nev ${ }^{\complement}$ üzerinedür. Dördi yürekde olur. Yürekde olanlarun biri kabż bevāṣīrdür. Biri ishāl bevāṣīrdür. Biri rīḥ bevāṣīiuür. Ve altısı mak adda olur. Biri [14a] zenbūrīdür. Uzunca arı gibi olur. Ve birine țut bevāṣīi dèrler. Dāne dāne olur. Ve birine 'inebì dẻrler. Üzüm gibi degirmi, ḳaraca olur. Ve birine şakāạ dẻrler ki yayılur, ḳanar. Ve birine nef ${ }^{c}-i$ bevāṣīi dèrler. Balık kurșagiına döner. Ve birisine nāṣīr-i bevāṣīi dèrler. Boynuz gibi kaysūde olur. Birine dahı raḥne-i bevāṣīi dèrler. Bunuy ortası delik olur. İçinden irin ve necāset gelür. Bu maḳ aduy altından gelür. Cümlesine maraż-1 bevāșīi dẻrler.

Z̄ātü'l-cenb: Dẻrler bir marażdur. Ve

Serețān: Dėrler bir marażdur. Teni şişer ve yanar. Ve

Ḥamām-1 erba': Dahı̣ bir marażdur. Ve

Cemre: Ya'nī yaḳmaca maraż.

Sevdā-yı cünūn: Bir marażdur. Ve

Mālihūlyā: Başda olur bir marażdur.

İstirhạa-yı 'așab marażı: Eṭibbā ḳatında ma' rūfdur.

Lakvve: Dėrler bir marażdur. Yüzi gözi egilür.

Maḥmūm: Bir marażdur. Vücūdında issi yèl gibi gezer.

Sersām rencī: Dèrler bir rencdür.

Ḥancere: Bog̉az ag̉rısına dèrler.

Ḥaffām: Ol renc dahı̆ı bog̉azda olur.

Dâ'ü'l-fî̀l: Bir marażdur ki ayaḳda ve baldırda gaāyetle şişer ve yoġun olur.

Tatar kurdı: Ki ana göbek burusı dërler.

[14b]

Vücū'ü’l-kelb: Dahı bir ag̉rıya dẻrler.

Fālice: Bir marażdur.

Teşennüc: Sinir burulmasına dèrler.

Ḩader: Türkçe uyuşmaġa dèrler. 
Remed: Göz ag̉rısına dèrler.

Kan ishāli: Ve kurūḥ.

Nāzle: Cemīc cillet nāzleden ḥāṣıl olur.

Bögrek țaşı: Bir marażdur.

Sīne 'illeti: Kim ḳan ve verem gelür.

Heyża: Dėrler bir marażdur.

Kābūs: Fārisī pür-hafec, Türkçe ag̉ır bașmaḳ dèrler ve baş çegzinmek de dẻrler.

Küzāz: Sinir ḳınmasına dèrler.

Ḥunnāk: Boġazda bir dilçükdür, bir ag̉rıdur.

Lāḳve: Ana dèrler ki gözi ve ag̉zı egilse.

Fitık: Kasık yaruġ 1 'illetidür.

Remed: ‘Arabça göz ag̉rıs1.

Ber-cūşīde: Ḳurdeşeni dèdükleri 'illetdür.

Beryūn: Kurlug̉an 'illeti. Dırnaḳda olur. Gāh olur dırnaġı düșer ve demregi.

Baraṣ: Bir marażdur ki teni alaca olur. Türkçe abraş dèrler.

Ḥalāşime: Tuḥme șayrulıġ ve bog̉az ile burun arasında olur bir 'illetdür. Tuḥmeden ḥāṣıl olur.

Ḥummā-yı muhriḳa: Yánī derleme hastaligìdur.

El-kābūs: Uykuda aġır bașmak.

İnḥidar: Endāmlar uyuşmak.

Zükām: Burun dutulmak.

Kurha: Göz kabarcı̀̇ı.

Ez-zufre: Gözde olan dırnak.

Hadāka: Göz bebegin kan ve çapak örtmek 
'Așāve: Göz ḳararmaḳ.

El-intişār: Göz delügi sızlamak.

Şarnāk: Göz ḳapaġı aġır olmaḳ.

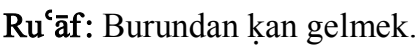

El-ḥaşem: Burun ḳoḳu eylememek.

\section{Sonuç}

Çalışmamıza konu olan müellifi bilinmeyen bu isimsiz tıp sözlüğünün içinde 3 fasıl bulunmaktadır. Baş tarafı eksik olan çeşitli tıbbî bitki adlarından oluşan ilk fasılda madde başı olarak 415 bitki adı yer almaktadır. Bunlardan 17'si tekrarlanmış olup açılımalarında farklılıklar bulunmaktadır. Sözlükte Arapça kökenli bitki adları sayıca en fazla olup ardından Farsça, Türkçe, Boşnakça, Hintçe, Ermenice sözcükler gelmektedir.

Eserde bulunan ikinci fasıl insan tabiatlarının özellikleriyle ilgili olup genel açılamalardan ibarettir. Eserin son bölümü, birçok hastalık adının verildiği bir fasıldır. Bu bölümdeki sözlükte madde başlarında bulunan hastalık adlarının sayısı 103'tür. Bu hastalık adlarından 8'i birden fazla kez tekrarlanmış olup açıklamaları değişiklik göstermektedir. Ağırıklı olarak Arapça, Farsça olmak üzere Türkçe hastalık adlarının da madde başı olarak verildiği görülmektedir.

Başı eksik olan bu tıp ve ecza sözlüğünde madde başı 518 terim yer almaktadır.

Herhangi bir tarih kaydı bulunmayan eserin Klasik Osmanlı Türkçesi özellikleri gösterdiği ve müstakil tıp-ecza sözlüklerinin yazılmasına 17. yüzyıldan sonra başlandığı göz önünde bulundurulduğunda 17 ve 18. yüzyılda yazıldı̆̆ söylenebilir.

İçeriğinde birçok tıbbî bitki, deva ve hastalık adlarının ve tanımlarının yer aldığı bu sözlüğün özellikle Boşnakçaya ait sözcükleriyle tıp metinleri, tıp-ecza sözlükleri alanına katkı sağlayacağı umulmaktadır.

\section{Kaynakça}

Ahmed İssa Bey (1930). Dictionnaire des Noms des Plantes, en Latin, Français, Anglais et Arabe. Le Caire: Imprimerie Nationale.

Aydın-Zülfikar, M. B. (2012). Terceme-i Kitâbü'l-Filâha (Zootekni Kısmı). İstanbul: Kitabevi Yayınları.

Baytop, T. (2007). Türkçe Bitki Adları Sözlüğü. Ankara: TDK Yayınları.

Bedevian, K. A. (1936). İllustrated Polyglottic Dictionary of Plant Names in Latin, Arabic, Armenian, English, French, German, Italian and Turkish Language. Kahire: Argus and Papazian Presses.

Canpolat, M., Önler Z. (2007). İshâk bin Murâd, Edviye-i Müfrede. Ankara: TDK Yayınları.

Doğan, Ş. (2011). "XV.-XVIII. Yüzyıllar Arasında Anadolu Sahasında Türkçe Yazılmış Tıp ve Eczacılık Sözlükleri”. IV. Uluslararası Dünya Dili Türkçe Sempozyumu Bildiri Kitabı. Mehmet Naci Önal (Ed.). Muğla: Muğla Sıtkı Koçman Üniversitesi Yayınları. 2, 103-114.

Kırkkılıç, A., Sancak, Y. (2017). Ahterî-yi Kebir. Ankara: TDK Yayınları.

Köksal, M. F., Kaçar,M., İlhan, M. (2018). Prof. Dr. Mehmet Fatih Köksal Kütüphanesi Türkçe Yazmalar Kataloğu. İstanbul: Kesit Yayınları. 
Küçüker, P. (2010). Mücerreb-nâme. Ankara: Kültür Ajans Yayınları.

Murad, S. (2009). Lügat-ı Müşkilât-ı Eczâ (Giriş-İnceleme-Metin-Dizinler). Yayımlanmamış yüksek lisans tezi. Sakarya Üniversitesi Sosyal Bilimler Enstitüsü. Sakarya.

Önler, Z. (1999). Celâlüddin Hızır Paşa, Müntahab-ı Şifâ II Sözlük. Ankara: Simurg Yayınları.

Redhouse, J. W. (1987). A Turkish and English Lexicon, Sheving in English the Significations of the Turkish Terms. Beyrut.

Steingass, F. (2005). A Comprehensive Persian-English Dictionary. İstanbul: Çağrı Yayınları.

\section{Örnek Sayfalar}

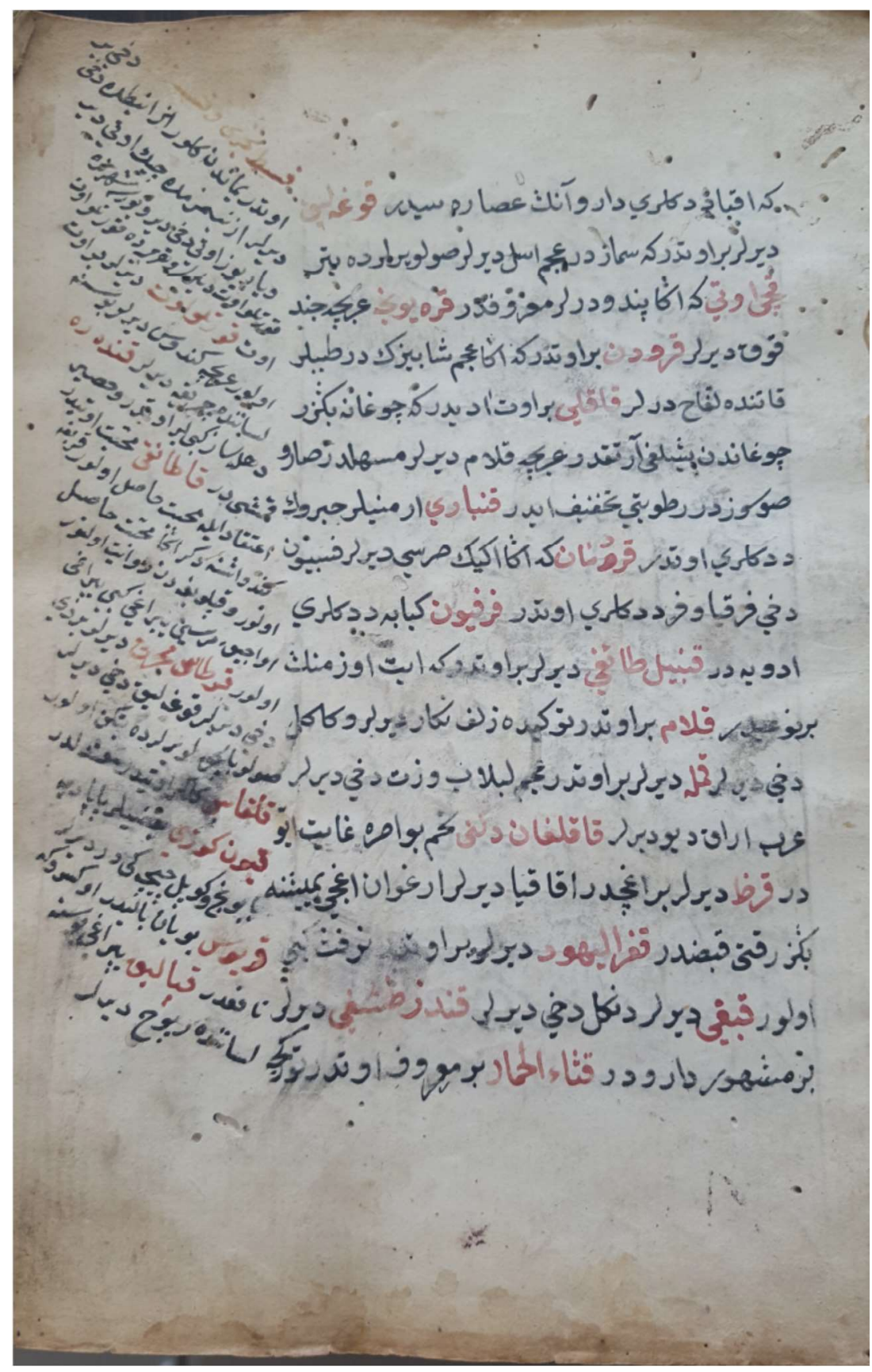

[1a] 


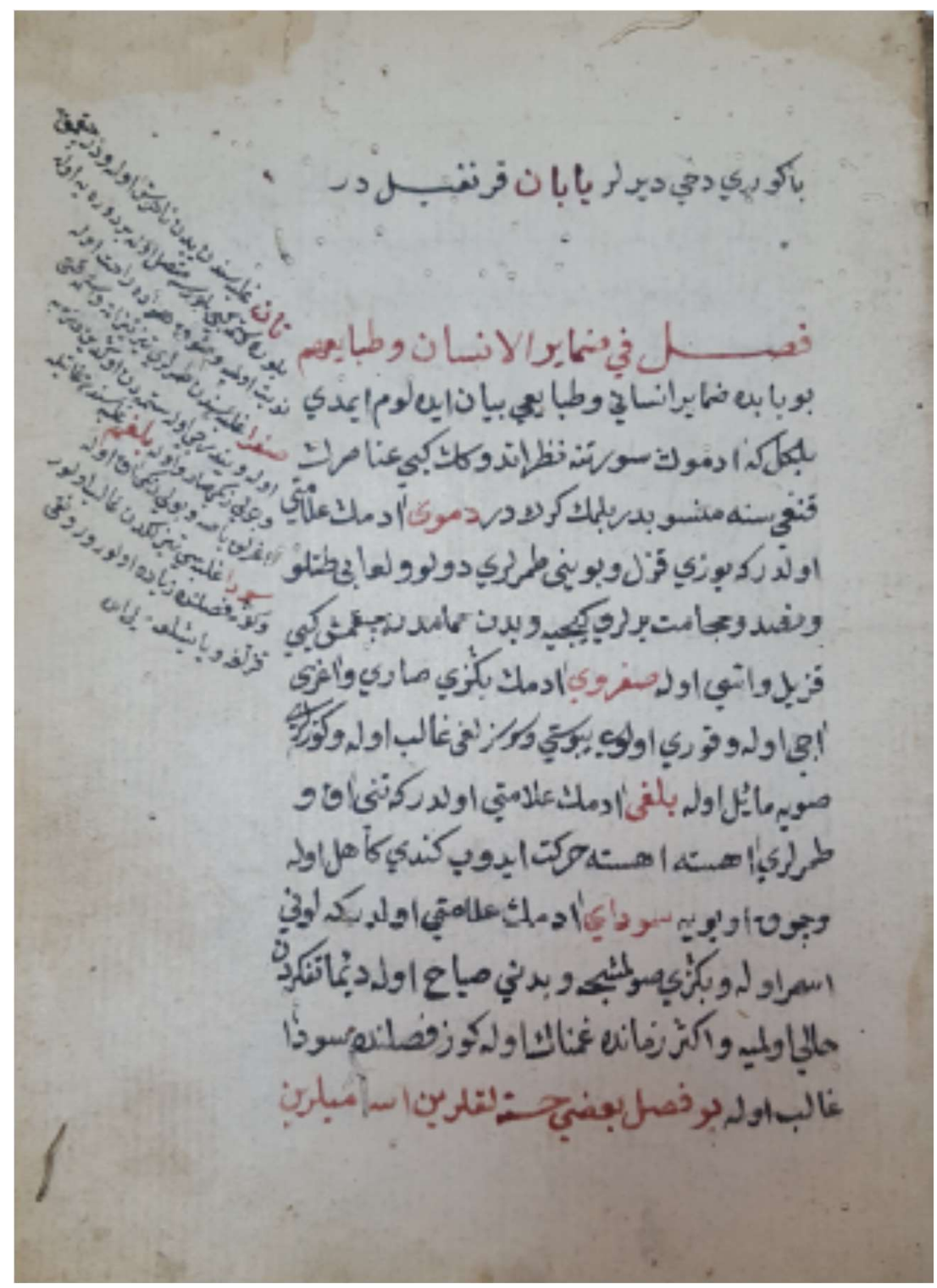

\section{[11a]}

